\title{
Acetaminophen (Paracetamol) induced acute liver failure - A social problem in an era of increasing tendency to self-treatment
}

\author{
Tadeusz Wróblewski', Konrad Kobryń', Sławomir Kozieł', Urszula Ołdakowska-Jedynak², \\ Jarosław Pinkas ${ }^{3,4}$, Roman Danielewicz ${ }^{5,6}$, Bogna Ziarkiewicz-Wróblewska ${ }^{7}$, Marek Krawczyk ${ }^{1}$ \\ ${ }^{1}$ Department of General, Transplant \& Liver Surgery, Medical University of Warsaw, Poland \\ ${ }^{2}$ Liver and Internal Medicine Unit of Department of General, Transplant \& Liver Surgery, Medical University of Warsaw, Poland \\ ${ }^{3}$ Centre of Postgraduate Medical Education, Warsaw Poland \\ ${ }^{4}$ Ministry of Health, Warsaw, Poland \\ 5 Polish Transplant Coordinating Center "Poltransplant", Warsaw, Poland \\ ${ }^{6}$ Department of Surgical and Transplant Nursing, Medical University of Warsaw, Poland \\ 7 Department of Pathology, Medical University of Warsaw, Poland \\ Wróblewski T, Kobryń K, Kozieł S, Ołdakowska-Jedynak U, Pinkas J, Danielewicz R, Ziarkiewicz-Wróblewska B, Krawczyk M. Acetaminophen \\ (Paracetamol) induced acute liver failure - A social problem in an era of increasing tendency to self-treatment. Ann Agric Environ Med. 2015; \\ 22(4): 762-767. doi: 10.5604/12321966.1185790
}

\begin{abstract}
Introduction.The widespread availability of medication without prescription, so-called over the counter (OTC), and the rapid development of health consciousness of Poles is associated with broad access to medical information in the mass media. This causes patients to recognize their own disease, cancel doctor's appointments, and begin self-treatment. This time and money-saving behavior, often signaled by pain, usually leads to the treatment of symptoms alone, without seeking the cause of the disease.The aim of the study was to present life-threatening paracetamol poisoning, and the treatment of acute liver failure.

Material and Methods. In 2002-2014, 35 patients were hospitalized due to acute paracetamol poisoning: 17 female and 18 male patients aged between 17-59 (mean 32.3 years). Patients were treated in the surgical intensive care unit, where their parameters of liver and renal function were continuously monitored. If there was no improvement in the liver function, patients underwent albumin dialysis with the Prometheus system and were qualified for liver transplantation (LTx).

Results. 26 patients were treated pharmacologically and 7 out of 9 patients who underwent LTx were dialyzed. Overall, 11 patients had 26 albumin dialysis in total; 4 patients died - 1 post-transplant and 3 pre-transplant.

Conclusions. Paracetamol is the cause of many poisonings resulting from the lack of public awareness about toxic interactions with alcohol, and suicide attempts. Acetaminophen-induced acute liver failure concerns a small percentage of patients but can be successfully treated with albumin dialysis, and in extreme cases by liver transplantation.
\end{abstract}

Key words

acute liver failure, liver transplantation, over the counter drugs, acetaminophen poisoning

\section{INTRODUCTION}

The rapid development of the health consciousness of Poles is associated with broad access to medical information. Television, press, and above all the Internet, give patients almost unlimited access to information so that they can recognize their own disease, cancel doctor's appointments, and begin self-treatment. This time and money-saving behaviour often signaled by pain, usually leads to the treatment of symptoms alone, without seeking the cause of the disease. Such a procedure is favoured by the broad availability of medication without prescription - over the counter (OTC), often advertised in the mass media, and have consistently gained importance in the health care system. Thus, acetaminophen (paracetamol) is one of those drugs.The aim of the study is to present lifethreatening paracetamol poisoning, and treatment of acute liver failure occurring after excessive drug ingestion and problems arising from its improper use.

Address for correspondence: Tadeusz Wróblewski, Department of General, Transplant and Liver Surgery, Medical University, Banacha 1a, 02-097 Warsaw, Poland

e-mail:wroblewskitad@wp.pl

Received: 20 September 2015; accepted: 02 December 2015

\section{MATERIALS AND METHOD}

In 2002-2014, 35 patients were hospitalized due to acute paracetamol poisoning (PP). Patients diagnosed with severe poisoning were referred from Toxicology Centres across Poland as potential candidates for LTx. There were 17 women and 18 men aged from $17-59$ years (mean 32.3 years) among the cohort. Patients were managed in the surgical intensive care unit (S-ICU), where their parameters of liver and renal function were continuously monitored. Blood tests were performed every 3 hours and the laboratory results of biochemistry and morphology plus coagulation factors were assessed, respectively. Arterial blood gas tests were run every hour throughout the first 24-hours of intensive care. Hepatic encephalopathy was assessed according to the West Haven Scale (WHS) (Tab. 1), while hepatic coma according to the Glasgow Coma Scale (GCS) and computed tomography (CT) imaging was performed routinely [1]. Hepatic encephalopathy management varies depending on the acuity of liver failure. However, in patients with either acuteor chronic liver failure, 5 basic steps in management are critical: stabilization, addressing modifiable precipitating factors, lowering blood ammonia, managing elevated intracranial pressure (ICP) (if present), and 
Table 1. West-Haven Criteria for Hepatic Encephalopathy (HE)

\begin{tabular}{|c|c|c|c|}
\hline Grade & Consciousness & Intellect and Behavior & NeurologicFindings \\
\hline 0 & Normal & Normal & $\begin{array}{l}\text { Normal examination; if } \\
\text { impaired psychomotor } \\
\text { testing, consider MHE }\end{array}$ \\
\hline 1 & $\begin{array}{l}\text { Mildlack of } \\
\text { awareness }\end{array}$ & Shortenedattentionspan & $\begin{array}{l}\text { Impaired addition or } \\
\text { subtraction; mild asterixis or } \\
\text { tremor }\end{array}$ \\
\hline 2 & Lethargic & $\begin{array}{l}\text { Disoriented; } \\
\text { Inappropriatebehavior }\end{array}$ & $\begin{array}{l}\text { Obviousasterixis; Slurred } \\
\text { speech }\end{array}$ \\
\hline 3 & $\begin{array}{l}\text { Somnolent } \\
\text { but arousable }\end{array}$ & $\begin{array}{l}\text { Gross disorientation; } \\
\text { Bizarrebehavior }\end{array}$ & $\begin{array}{l}\text { Muscular rigidity and clonus; } \\
\text { Hyperreflexia }\end{array}$ \\
\hline 4 & Coma & Coma & Decerebrateposturing \\
\hline
\end{tabular}

managing complications of liver failure that can contribute to encephalopathy, particularly hyponatremia $[2,3]$.

Increase in transaminase levels, coagulation deficiencies, as well as impaired consciousness including coma, were signs indicating patients for urgent LTx, based on the King's College Criteria (Tab. 2) [4]. While waiting for a donor liver, the patients were treated with albumin dialysis with the use of FPS-Prometheus. $\mathrm{N}$-acetylcysteine administration was continued according to paracetamol poisoning treatment guidelines. Extreme coagulant deficiency was supplemented with packed fresh frozen plasma (pFFP) transfusions, and in patients with elevated risk of bleeding, an intravenous (i.v.) infusion of prothrombin complex concentrate (Octaplex - Octapharma, Coventry, UK) was administered. Factors denying the patient albumin dialysis were: persistent low blood pressure (systolic blood pressure, $\mathrm{SBP}<55 \mathrm{mmHg}$ ) despite continuous infusion of amine pressors, signs of active bleeding, regardless of its source, clinical features of central nervous system herniation, symptoms of disseminated intravascular coagulation (DIC) and thrombocytopenia of consumption.

Table 2. King's College Criteria for Acetaminophen-induced Acute Liver Failure

\begin{tabular}{l} 
Arterial $\mathrm{pH}<7,3$ (Regardless of Hepatic Encephalopathy HE) \\
\hline or all $\mathbf{3}$ of the following: \\
\hline INR $>6,5$ \\
\hline Creatinine $>3,3 \mathrm{mg} / \mathrm{dl}(>300 \mu \mathrm{mol} / \mathrm{l})$ \\
\hline HE grade $3-4$
\end{tabular}

Since 2002, albumin dialysis has been performed using a system called Prometheus, which includes a Fresenius 4008 $\mathrm{H}$ unit and Fractionated Plasma Separation and Adsorption System (FPSA), comprised of an albumin filter Albu-Flow and 2 adsorption columns: Prometh-1 and Prometh-2 (Fresenius Medical Care AG, Bad Homburg, Germany) [4, 5]. During the first phase of the procedure, the blood of the patient flows through an albumin filter made of polysulfide (AlbuFlow), within which protein molecules of 400,000 Daltons in size are separated. Next, the albumins pass through a system of absorbers (Prometh-1 and Prometh-2). Within the absorbers, organic substances bind together, such as aromatic amino acids, phenols, bile acids and bilirubin (including indirect bilirubin). The purified albumins are recombined again with the blood, which in the second phase of the procedure, pass through a conventional dialyzing filter FX 50, where elimination of toxic
Table 3. Median laboratory values of cohort admitted to the Department with Acetaminophen-induced Acute Liver Failure as potential recipients of LTX

\begin{tabular}{lccc}
\hline Variables & Mean Value & Range & Normalvalues \\
\hline pH(venous) & 7.3 & $7,27-7,4$ & $7.32-7.42$ \\
\hline Prothrombintime (PT) & $63 \mathrm{~s}$ & $44->100 \mathrm{~s}$ & $15-18 \mathrm{~s}$ \\
\hline International Normalized Ratio (INR) & 3.8 & $2.4-7.6$ & $0.8-1.6$ \\
\hline Creatinine & $2.2 \mathrm{mg} / \mathrm{dl}$ & $\begin{array}{c}1.2-3.2 \\
\mathrm{mg} / \mathrm{dl}\end{array}$ & $<1 \mathrm{mg} / \mathrm{dl}$ \\
\hline Aspartateaminotransferase (AST) & $2400 \mathrm{U} / \mathrm{l}$ & $\begin{array}{c}1800-6750 \\
\mathrm{U} / \mathrm{l}\end{array}$ & $30 \mathrm{U} / \mathrm{l}$ \\
\hline Alanineaminotransferase (ALT) & $2300 \mathrm{U} / \mathrm{l}$ & $\begin{array}{c}1500-5200 \\
\mathrm{U} / \mathrm{l}\end{array}$ & $30 \mathrm{U} / \mathrm{l}$ \\
\hline Glycemia & $56 \mathrm{mg} / \mathrm{dl}$ & $\begin{array}{c}42-76 \\
\mathrm{mg} / \mathrm{dl}\end{array}$ & $\begin{array}{c}60-100 \\
\mathrm{mg} / \mathrm{dl}\end{array}$ \\
\hline Platelets (PLT) & $30 \mathrm{G} / \mathrm{l}$ & $15-70 \mathrm{G} / \mathrm{l}$ & $120-250 \mathrm{G} / \mathrm{l}$
\end{tabular}

substances soluble in water (including ammonia, urea, and creatinine) is carried out. Subsequently, through the venous line, the blood is returned to the patient. The treatment is carried out using double-channel dialyzing catheters.

Liver transplantation, similar to cases of elective transplants, herein selection criteria of the donor to the recipient are based upon compatibility of blood groups: ABO. In many cases of $\mathrm{PP}$, however, transplantation of a mismatched liver graft is unavoidable. Such a situations occur when the systems of albumin dialysis and blood filtration do not improve the general health management of patients and their condition steadily worsens. In patients with acute liver failure (ALF), including paracetamol poisoning, due to the lack of collateral circulation detouring the liver which is usually present in patients with a chronic hepatic disease leading to cirrhosis, LTx is routinely performed with the use of an extra-corporeal veno-venous bypass. Cannulas for the bypass are inserted into the femoral and portal veins, through which blood is pumped by the bio-pump [6,7]. The liver is then always removed along with the intrahepatic inferior vena cava this type of LTx is named classic liver transplantation. The blood flow induced by and through the bio-pump begins the surgical procedure and carries on throughout until all venous anastomosis have been performed (Figs. 1, 2). De-cannulation is performed routinely after venous reperfusion of the liver graft and before the arterial anastomosis. Transplantation is completed following the biliary anastomosis.

\section{RESULTS}

There were 35 patients referred to the Department of General Transplant and Liver Surgery at the Medical University in Warsaw as potential candidates for liver transplantation, all of whom were transferred from other centers providing treatment following toxic poisoning in Poland. They were patients in whom treatment with $\mathrm{N}$-acetylcysteine was unsuccessful, and liver function tests as well as the neurological condition had systematically worsened. Assessing the state of consciousness of these patients using the WHS, it was found that 10 of them (28.5\%) were in grade 0,22 patients $(63 \%)$ in grades II and III, and 3 patients in grade IV of hepatic coma. When assessing the general condition of patients by the Kings College classification, more than a half of the patients (19/35) qualified for albumin dialysis and LTx 


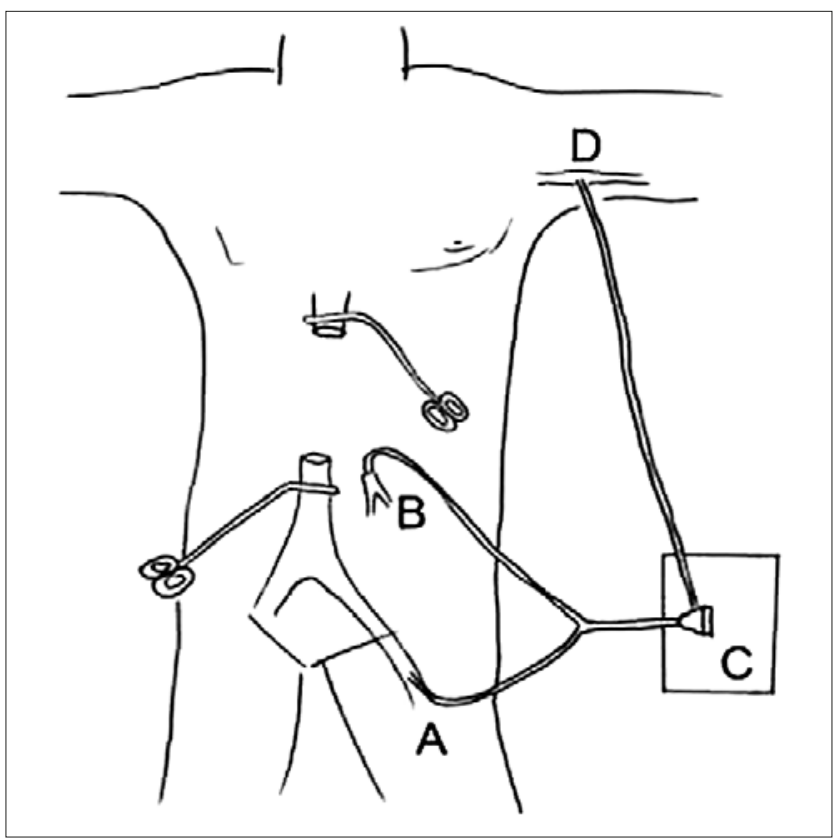

Figure 1. Classic technique of Liver Transplantation. Drawing of the removed liver along with the intrahepatic inferior vena cava and extracorporeal veno-venous bypass with cannulation of the femoral vein (A), portal vein (B) and axillary vein (D). Biopump (D)

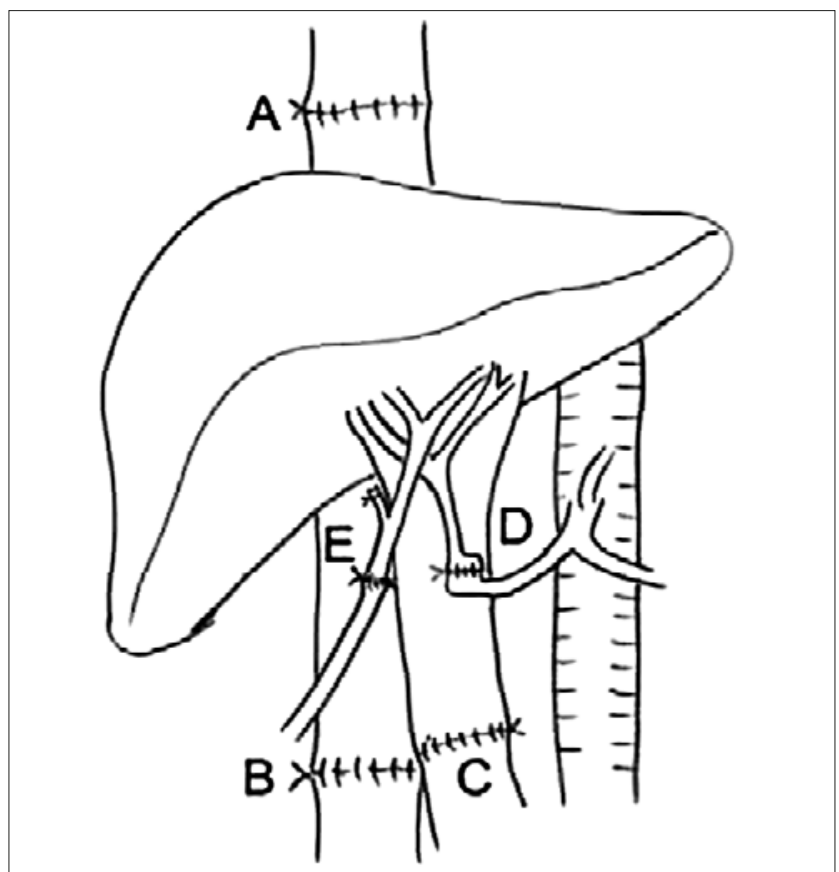

Figure 2. Classic technique used in patients with acetaminophen-induced ALF. Transplantation of new liver graft with end-to-end suprahepatic (A), infrahepatic (B) veno-venous anastomosis. Portal (C), arterial (D), biliary (E) anastomosis [5]

on admission to the hospital. Significant coagulant disorders and anaemia were leveled out on a regular basis through pFFP and packed red blood cell ( $\mathrm{pRBC}$ ) transfusions. On average, a transfusion rate of 6 units of pFFP and 4 units of pRBC per patient were noted. In 5 cases, haematuria was observed and treated with repetitive saline flushing of the bladder through a 3-way Foley catheter. In one case, there was a tamponade of the bladder due to blood clot accumulation as a result of concomitant narrowing of the urethra. This was treated by performing a percutaneous cystostomy and inserting a cystoscope, and mechanically crushing the formed clots into smaller ones in order to empty the bladder of the residing content with suction. Once only debris was left, a 20FR 3-way Foley catheter was implemented for intensive and continuous flushing of the contents with saline solution.

In 11 cases, gastrointestinal bleeding (GIB) occurred and was treated endoscopically. Only in 3 cases it turned out to be bleeding from ruptured varices of the esophagus and gastric fundus, which occurred in patients with concomitant alcoholic cirrhosis of the liver after ingestion of a significant quantity of paracetamol. These patients were initially treated with endoscopic variceal banding, and the injection of n-Butyl-2-Cyanoacrylate tissue glue into the gastric varices. Due to the severe coagulopathy, treatment of esophageal and cardia varices was unsuccessful. Therefore, in the above cases, a $30 \mathrm{~mm}$ in diameter, $20 \mathrm{~mm}$ wide $135 \mathrm{~mm}$ long, covered, self-expandable DANIS stent (ELLA-CS, Czech Rep.) was applied. The stent was placed endoscopically, by compressing the ruptured varices of the esophagus and cardia until the bleeding stopped.

11 patients who were admitted to the Department underwent 26 sessions of dialysis in total. Liver transplantation was performed in 9 patients, of whom 7 had albumin dialysis preceding LTx, which represents $25 \%$ of all patients treated due to paracetamol poisoning. During all the liver transplantations, 2 units of the coagulant concentrate Octaplex was routinely administered. In these patients, it was possible to perform 2-3 sessions of albumin dialysis prior to transplantation. One patient died after LTx on the $5^{\text {th }}$ fifth post-operative day due to central nervous system hemorrhageof the brain stem. The remaining patients survived liver transplantation and the postoperative course was uneventful.

The remaining 26 patients were not treated surgically. In this group, albumin dialysis was performed in 4 patients. One patient survived following 3 sessions of albumin dialysis, but 3 patients died. They could not be considered for liver transplantation due to their severe condition and neurological symptoms as a consequence of coagulation disorders and haemorrhage to the ventricles of the brain. The median duration of one session of albumin dialysis was 7.5 hours. The shortest treatment lasted for 6 hours, the longest 9 hours and 59 minutes. One procedure was completed before the scheduled time due to increasing signs of heart failure with a significant drop blood pressure below $50 \mathrm{mmHg}$. In the remaining 22 patients, after intensive care, monitoring of vital signs and equalization of coagulant disorders, together with fluid and electrolyte management, a gradual improvement in general condition and normalization of liver function was observed. In total, 31 of the 35 patients $(88.8 \%)$ survived acute paracetamol poisoning, including the 8 patients who underwent liver transplantation. The outcomes of treatment are characterized in Table 4 . The length of stay in the Department ranged from 1-45 days (mean 11.7 days).

Table 4. Acetaminophen-induced ALF group characteristics

\begin{tabular}{lccc}
\hline & LTxgroup & Non-LTxgroup & Total \\
\hline No. ofPatients & 9 & 26 & 35 \\
\hline PatientstreatedwithoutPrometheus & 2 & 22 & 24 \\
\hline PatientstreatedusingPrometheus & 7 & 4 & 11 \\
\hline Mortality & 1 & 3 & 4 \\
\hline
\end{tabular}




\section{DISCUSSION}

According to the World Health Organization (WHO), the definition of 'self-medication' is understood as the use of drugs by a consumer to treat diseases or symptoms identified by himor herself. These are primarily non-steroidal anti-inflammatory drugs (NSAID) (57\%), other supplements used for common colds and influenza (19.5\%), vitamins and minerals (13.5\%), in the minority, cardiac (5\%) and colic medication (2\%). As many as three-quarters of Poles state that they use OTC medication without medical consultation [8].

Self-medication drugs are not a homogeneous group of products. Taking into account the criteria related to their use and purpose, 4 main categories can be distinguished:

1) medication available without a prescription;

2) nutritional supplements;

3) dietary foods for particular nutritional uses;

4) medical wares.

Drug-induced liver injury (DILI) is defined as a liver injury due to xenobiotics, herbs, or medications that leads to either liver dysfunction or abnormal liver serology, in the setting of no other identifiable cause. DILI has been associated with more than 1,000 medications and in the United States is the most common cause of acute liver failure, accounting for approximately $50 \%$ of fulminant cases. While retrospective studies have shown acetaminophen to be the most common cause of DILI, studies in liver transplant patients have demonstrated antibiotics and immunosuppressive agents, such as tacrolimus and azathioprine, as the top causes [9, $10,11]$. In the USA, the OTC market represents $5 \%$ of the entire pharmaceutical market. It would seem that this is a small part, but the value of the entire drug market is $\$ 290$ billion, of which OTC drugs account for about $\$ 15$ billion [12]. The USA is considered to be a country with easy access to medicines without a prescription, has high current safety requirements, and is a country in which satisfaction with the use of drugs without a prescription is the greatest. Such satisfaction is declared by up to $92 \%$ of people taking selfmedication (compared with $83 \%$ in the UK, $80 \%$ in Canada and $75 \%$ in Australia) [13]. In the UK, the market for OTC medication represents nearly $16 \%$ of the pharmaceutical market, which amounts to almost $£ 3$ billion a year [14].

The Polish market of OTC drugs takes just over onequarter $(26 \%)$ of the value of the pharmaceutical market and relatively represents the highest value in the Europe Union [15]. Relatively, because in Poland OTC medication is expensive, the high market value therefore does not mean that the Poles consume significantly more of these drugs than other nations. In 2013, the value of the segment of products without prescription amounted to 8.9 billionPLN in pharmaceutical sales, which was an increase of $5.8 \%$ compared to 2012. The biggest share in sales was represented by the category of products registered as OTC (5.8 billion PLN), which recorded an increase of $4.0 \%$ compared to 2012. The dietary supplements category, when it comes to their placement in the entire segment, ranks second $(2.3$ billion PLN), also being an increase of $7.1 \%$ compared to 2012. The increase in value does not stem only from the increased consumption of drugs, but also from the increase in their prices.

The widespread availability of paracetamol and accumulation of the drug, which can be found in different complex formulations and under a variety of brand names, called polypharmacy, can lead to acute poisoning, especially through suicide attempts involving the ingestion of significant quantities of pills easily purchased everywhere (petrol stations, grocery stores and supermarkets) cause significant damage to hepatocytes and the manifestation of acute liver failure. Patients with acute paracetamol poisoning account for only a small percentage of the total number of patients treated in toxicology departments. The majority of toxicity cases, including ALF, associated with the ingestion of paracetamol were due to chronic poisoning. This finding constitutes an important warning regarding paracetamol chronic poisoning, and clinicians should have a higher index of clinical suspicion for this entity $[16,17,18,19,20]$.

In Poland, there is no central data and patients' recording system for those who experienced toxic poisoning. Based on data by courtesy of the directors of 8 of the 10 Toxicology Centres treating patient poisonings in Poland, an estimated 800-1,000 patients are treated due to paracetamol poisoning per year. However, only a fraction of this group, representing less than $5 \%$, present severe poisoning. Among them, the largest group of over $70 \%$ of paracetamol ingestion and poisoning are due to suicide attempts, $20 \%$ is represented by patients combining high doses of acetaminophen with alcohol, while the remaining 10\% stand for all forms of polypharmacy. The great majority of patients treated because of drug poisoning come from urban environments.

All patients with severe hepatic impairment transferred to the Department are initially placed in the S-ICU. During the intensive monitoring of vital signs in this group of patients, symptoms of gastrointestinal bleeding were observed which required urgent diagnosis and endoscopic treatment. A particular problem involved patients in whom paracetamol poisoning imposed on co-existing liver cirrhosis and portal hypertension. Bleeding from the upper gastrointestinal tract was contained by esophageal variceal banding, injection of histoacryl tissue glue in the gastric fundus varices, and ulcers of the stomach and duodenum [21].

Unsuccessful management of GIB with the use of the above-mentioned methods required their temporary compression through the use of self-expandable stents placed endoscopically in the esophagus. This solution originated through many years experience when managing perforations of the esophagus in advanced cancer which prevented mediastinitis. Once the haemorrhage had been stopped and the patient's general condition significantly improved, the stent was removed endoscopically no later than 10 days after the procedure $[22,23,24]$. Signs of tamponade of the bladder by blood clots was an indication for continuous flushing of the bladder with saline through a 3-way Foley catheter. In one case, a patient with a constricted urethra was treated by performing a percutaneous suprapubic cystostomy, inserting a cystoscope, and mechanically crushing the formed clots into smaller ones in order to empty the bladder of the residual content with suction. Once only debris was left, a 20FR 3-way Foley catheter was implemented for the permanent flushing of the contents with saline solution [25]. Situations in which signs of hepatic failure progress, make these patients eligible for liver transplantation, which is the only effective treatment $[26,27]$. Unfortunately, the waiting time for a liver transplant from a deceased donor is sometimes prolonged, even though the patients are reported to the national coordinating institution (Poltransplant), placing donor organs in Poland 
for a super-urgent recipient. In such cases, the albumin dialyzing systems are used if vital signs allow this therapy. New methods of utilizing the conventional process of extracorporeal haemodialysis and the phenomenon of filtration and adsorption, which are designed to eliminate toxins accumulated as a result of the impairment of detoxification in the course of liver failure, are the Single-Pass Albumin Dialysis (SPAD), Molecular Adsorbents Recirculating System (MARS) and Prometheus System. The basis of the first 2 methods is albumin dialysis. The Prometheus system of albumin dialysis is a new type during which albumins are isolated from the patient's blood - Fractionated Plasma Separation and Adsorption System (FPSA). This system is a combination of classical haemodialysis and the FPSA methods developed by Falkenhagen in 1999. In the presented group of patients during procedures performed by the Prometheus system, its detoxification effect was primarily observed.

The use of filter FX50 and absorbers allows for a significant reduction of ammonia and bilirubin in serum concentrations. An increased concentration of ammonia in the serum causes adverse effects on the central nervous system, leading to the development of cerebral oedema, which has been shown in several studies. In patients with symptoms of hepatorenal syndrome, a significant reduction in the serum levels of creatinine and urea were noted and urine flow was obtained. This treatment also assisted in aligning the acid-base and water-electrolyte disorders. It seems that albumin dialyzing systems such as MARS and Prometheus can be used in the symptomatic treatment of patients with hepatic failure before the planned organ transplantation. Evaluation of the effectiveness of this method, however, requires the continuation of clinical trials on a larger group of patients [28].

At the Department of General, Transplant and Liver Surgery of the Medical University in Warsaw, by the end of 2013 more than 1,500 liver transplantations from deceased donors had been performed. In the case of liver transplantation for acute liver failure caused by paracetamol and Amanita Phalloidespoisoning, LTx was routinely performed with the use of extra-corporeal veno-venous bypass for the reason that this minor group of patients does not present hepatic cirrhosis and portal hypertension, and therefore have no collateral circulation bypassing the liver. In these patients, closure of the portal vein during a typical liver transplantation performed in the Department using the piggy-back technique, can cause sudden retention and hypertension at the confluenceof the portal vein. This results in excessive amounts of potassium ions being released from hypoxic cells into the portal bloodstream, creating lactic acidosis. The effect of this may be a severe post-reperfusion syndrome, presenting itself as a dynamic drop in blood pressure, cardiac arrhythmias, including cardiac arrest and death in asystole at the time of reperfusion of the transplanted liver. After each transplantation, therapy is needed against graft rejection by the host, and therefore administration of immunosuppressive drugs is necessary and must be continued throughout the duration of the recipient's life. Firstly, this enables the functioning of the graft, but secondly, it also weakens the immune system of recipients, promoting the development of infections and tumors, in particular, post-transplant lymphoproliferative diseases.

The estimated annual cost of treating acetaminophen poisoned patients in Poland is approximately 5 million
PLN which, in comparison to the value of the OTC market, represents $1 / 200$ of its value [29]. Unfortunately, in Poland, there is no central database of drug poisonings. It is therefore difficult to draw conclusions and establish trends and strategies for prevention protocols. Shifting a few percent of income on awareness-raising campaigns of the dangers accompanying drug overdose could improve the knowledgeable use of drugs with less possibilities of overdose. Suicide attempts often using paracetamol, however, cannot be avoided, although in the literature there are opinions that these drugs should continue to be sold without a prescription, but only by pharmacies and drug stores. In cases of drug overdose, only the speed of response in patients in whom attempted suicide is suspected can be improved by implementing treatment with the appropriate antidote. In Poland, there are many centres with albumin dialyzing systems, which are of particular importance and application in liver transplant centres. However, the life-saving procedure in the most severe cases of paracetamol-induced acute liver failure remains liver transplantation, but in Poland there are only 5 such liver transplant centres.

\section{CONCLUSIONS}

It must be emphasized that in Poland it is necessary to immediately build a centralized, computerized registry of poisonings and outcomes of poisoning-treated patients. Analyzing the data collected in such a registry would allow not prevent self-treatment, but indicate a far-reaching prevention of poisonings and rational self-medication. The huge promotion of OTC drugs in the media and lack of social education towards consumer awareness of possible and very serious side-effects of acetaminophen poisoning leads to common abuse of this drug. Fortunately, however, with the particular educational problems faced in the rural environment, few people die of paracetamol overdoses due to very early detoxification treatment. Acute liver failure in the course of paracetamol poisoning, usually through suicide attempts, is explained in the medical part of this study. The section also includes treatment for the most severe forms of poisoning treated with life supporting albumin dialysis that prolongs patient survival until liver transplantation. The presented acute complications of paracetamol poisoning summarize what might happen in the case of further development of the OTC drug market in Poland, and the absence of a broad campaign expanding the awareness of society.

\section{REFERENCES}

1. Ferenci P, Lockwood A, Mullen K, Tarter R, Weissenborn K, Blei AT, et al. Hepatic encephalopathy-definition, nomenclature, diagnosis, and quantification: final report of the working party at the 11th World Congresses of Gastroenterology, Vienna. Hepatology 1998; 35(2002): pp. 716-721.

2. Frontera JA. Management of hepatic encephalopathy. Curr Treat Options Neurol. 2014 Jun; 16(6): 297.

3. Willars C. Update in intensive care medicine: acute liver failure. Initial management, supportive treatment and who to transplant. Curr Opin Crit Care. 2014 Apr; 20(2): 202-9.

4. Skwarek A, Grodzicki M, Kotulski M, Zieniewicz K, Krawczyk M. Zastosowanie systemu Prometheus ${ }^{\oplus}$ w leczeniu niewydolności wątroby przeszczepionej $\mathrm{w}$ przebiegu zakażenia wirusem HCV de novo. Wideochir Tech Małoinwaz. 2006; 2: 70-76 [in Polish]. 
5. Krawczyk M, Skwarek A, Grodzicki M. Zastosowanie systemu FPSA Prometheus w leczeniu chorych z niewydolnością wątroby. Post Nauk Med. 2006; 2: 72-78 [in Polish].

6. Cooper SC, Aldridge RC, Shah T, et al. Outcomes of liver transplantation for paracetamol (acetaminophen)-induced hepatic failure. Liver Transpl. 2009; 15: 1351

7. Wójcicki M, Pakosz-Golanowska M. Transplantacja wątroby- technika chirurgiczna i powikłania naczyniowe po operacji. Gastroenterol Klin. 2011; 3(1): 46-54.

8. CBOS. Komunikat z badań - Polacy o swoim zdrowiu oraz prozdrowotnych zrachowaniach i aktywnościach. Warszawa sierpień 2012. www.cbos.pl/PL/publikacje/raporty.php [in Polish].

9. Giordano Ch, Rivas J, Zervos X. Update on Treatment of Drug-Induced Liver Injury J Clin Trans Hepatol. 2014 Jun; 2(2): 74-79.

10. Chalhoub WM, Sliman KD, Arumuganathan M, Lewis JH. Druginduced liver injury: what was new in 2013? Expert Opin Drug Metab Toxicol. 2014 Jul; 10(7): 959-80.

11. Leise MD, Poterucha JJ, Talwalkar JA. Drug-induced liver injury. Mayo Clin Proc. 2014 Jan; 89(1): 95-106.

12. Czapiński J, Panek T. (red.). Diagnoza społeczna 2013. www.diagnoza. com [in Polish].

13. Gujski M, Kalbarczyk W. P. (red.). Zdrowie priorytetem politycznym państwa - analiza i rekomendacje. Warszawa 2013. www.ioz.org.pl [in Polish].

14. Główny Urząd Statystyczny - Prognoza ludności na lata 2008-2035 http://stat.gov.pl/obszary-tematyczne/ludnosc/prognoza-ludnosci/ prognoza-ludnosci-na-lata-2008-2035,1,1.html [in Polish].

15. Komisja Europejska. Report of the working group of promoting good governance of non-prescription drugs in Europe. czerwiec $2013 \mathrm{http}: / /$ ec.europa.eu/enterprise/sectors/healthcare/files/docs/otc_report_en

16. Tong HY, Medrano N,Borobia AM, Martínez AM, Martín J, Ruiz JA, et al. Hepatotoxicity induced by acute and chronic paracetamol overdose in adults. Where do we stand? Regul Toxicol Pharmacol. 2015 Jul; 72(2): 370-8.

17. Graudins A. Paracetamol poisoning in adolescents in an Australian setting: not quite adults. Emerg Med Australas. 2015 Apr; 27(2): 139-44.

18. Goldberg DS, Forde KA, Carbonari DM, Lewis JD, Leidl KB, Reddy $\mathrm{KR}$, et al.: Population representative incidence of drug-induced acute liver failure based on an analysis of an integrated health care system. Gastroenterology. 2015 Jun; 148(7): 1353-61.

19. Tiegs G, Karimi K, Brune K, Arck P. New problems arising from old drugs: second-generation effects of acetaminophen. Expert Rev Clin Pharmacol. 2014 Sep; 7(5): 655-62.

20. Michaut A, Moreau C, Robin MA, Fromenty B. Acetaminopheninduced liver injury in obesity and nonalcoholic fatty liver disease. Liver Int. 2014 Aug; 34(7): e171-9.

21. Kurek K, Baniukiewicz A, Świdnicka-Siergiejko A, Dąbrowski A. Application of cyanoacrylate in difficult-to-arrest acute non-variceal gastrointestinal bleeding. Videosurgery Mini Inv. 2014; 9 (3): 489-493.

22. Safranek J, Geiger J, Vesely V, Vodicka J, Treska V. Esophageal stents for less invasive treatment of mediastinitis. Videosurgery Mini Inv. 2014; 9 (1): 1-5.

23. Holster IL, Kuipers EJ, van Buuren HR, Spaander MC, Tjwa ET. Selfexpandable metal stents as definitive treatment for esophageal variceal bleeding. Endoscopy. 2013 Jun; 45(6): 485-8.

24. Dechêne A, El Fouly AH, Bechmann LP, Jochum C, Saner FH, Gerken G, Canbay A. Acute management of refractory variceal bleeding in liver cirrhosis by self-expanding metal stents. Digestion. 2012; 85(3): 185-91.

25. Gołabek T, Powroźnik J, Szostek P, Chłosta P, Borówka A. Percutaneous suprapubic endoscopy for treatment of bladder tamponade. Videosurgery Mini Inv. 2013; 8 (4): 364-365.

26. Schneider F, Poidevin A, Riehm S, Herbrecht JE, Guillot M. Liver transplantation in case of acetaminophen poisoning: importance of assessment of the colon if arterial lactate increases despite appropriate care. Transplantation. 2014 Jul 27; 98(2): e10-1.

27. Willey JZ, Tolchin BD. Liver transplant for intentional acetaminophen overdose and hepatic encephalopathy: a conflict between beneficence and justice. Continuum (Minneap Minn). 2014 Jun; 20(3 Neurology of Systemic Disease): 681-5.

28. Ghannoum M, Lavergne V, Gosselin S, Mowry JB, Hoegberg LC, Yarema $\mathrm{M}$, et al. Practice Trends in the Use of Extracorporeal Treatments for Poisoning in Four Countries. Semin Dial. 2015 Nov 9.doi: 10.1111/ sdi.12448. [Epub ahead of print]

29. Teter Z. (NFZ). NFZ - wydatki na pacjentów powyżej 65 roku życia. Prezentacja na Kongresie Zdrowego Starzenia. Warszawa 2014. www. zdrowestarzenie.org/baza-wiedzy.html 